\title{
Exploring the Distinctiveness of Neo-Latin Jesuit Didactic Poetry in Naples: The Case of Nicolò Partenio Giannettasio
}

\author{
Claudia Schindler
}

The Jesuit Nicolò Partenio Giannettasio (1648-1715) was one of the most intriguing and influential authors of seventeenth-century Naples. ${ }^{1}$ Born in 1648, in Parthenope (i.e., Naples), as he used to call his home city, he entered the Jesuit order at the age of sixteen, having lost his family during the plague of 1656. Like other members of the Society of Jesus, Giannettasio was a highly educated man with a wide range of interests: he studied Scholastic philosophy at Palermo, taught mathematics at the Collegio Massimo in Naples for more than ten years, traveled in Egypt, ${ }^{2}$ and designed the Santa Maria del Gesù church in Sorrento, which was built near the Jesuit residence La Cocumella and is still extant today. ${ }^{3}$

1 This chapter is a revised version of my German-language article, "Wissen ist Macht! Nicolò Partenio Giannettasio (1648-1715) und die neulateinische Jesuitenkultur in Neapel," Scientia poetica 18 (2014): 28-59. For the revision of the English text and for the Latin-English translations, I would like to thank Ronald Mayer-Opificius. For Giannettasio's biography, cf. Claudia Schindler, "Nicolò Partenio Giannettasios Nauticorum libri VIII. Ein neulateinisches Lehrgedicht des 17. Jahrhunderts," Neulateinisches Jahrbuch 3 (2001): 146-48; Yasmin Haskell, Loyola's Bees: Ideology and Industry in Jesuit Latin Didactic Poetry (Oxford: Oxford University Press, 2003), 70-76. The information provided by the biographical and bibliographical dictionary of Christian Gottlieb Jöcher (Allgemeines Gelehrten-Lexikon [Leipzig: Gleditsch, 1751], 3:309) and by the Nouvelle biographie générale (Paris: Firmin Didot frères, 1861), 34:col. 42829, as well as the text of the Biografia degli uomini illustri del regno di Napoli, ornata de' loro rispettivi ritratti (Naples: Nicola Gervasi, 1815), 3: s.v. "Giannettasio," are based upon the (partly autobiographic) pieces of information given within the biography which precedes the edition of Giannettasio's Opera poetica omnia of 1715 .

2 Cf. Yasmin Haskell, "Let the Mountain (Vesuvius) Come to Mahomet: The Healing Powers of Travel and Neapolitan Simpatia in Niccolò Giannettasio's Herculanean Spring (1704)," in Neapolitan Affairs (Variantology 5): On Deep Time Relations of Arts, Sciences, and Technologies, ed. Siegfried Zielinski and Eckhard Furlus (Cologne: Walther König, 2011), 273-90.

3 Giannettasio, Opera poetica omnia (Naples: Raillard, 1715), 1:7: "Ecclesiam a fundamentis ad culmen erexit, quae suis laboribus, etsi non satus aptum, at certe commodius theatrum esset futurum, cuius idem ipse Author fuit ac Architectus" [He built an entire church (from its foundation up to its roof), so that it—because of his labors—-would be-if not entirely

(C) CLAUDIA SCHINDLER, 2016 | DOI 10.1163/9789004313354_004

This is an open access chapter distributed under the terms of the Creative Commons Attribution-

Noncommercial-NonDerivative 3.0 Unported (CC-BY-NC-ND 3.0) License. 
Giannettasio was among the most productive of all neo-Latin authors. In prose, he composed two panegyrics (in 1699 and 1700) for Pope Innocent XII (r.1691-170o); the Historia Neapolitana (1713), a history of Naples, which consists of three volumes with more than fifty books; and the Annus eruditus (edited after Giannettasio's death by Antonio Fiani in 1722), which tackles scientific, philosophic, and historiographic problems in the manner of a Ciceronian dialogue. ${ }^{4}$ His poetic production comprises an epic poem on the life and voyages of the co-founder of the Society, Francis Xavier (1506-52), Saberides (1722), which he started in his early youth but left unfinished, ${ }^{5}$ the Piscatoria (1685), a collection of thirteen eclogues (fourteen in the second edition of 1686) situated within the idyllic landscape of the Bay of Naples, ${ }^{6}$ and an impressive amount of didactic poetry, totaling thirty-five thousand hexametric verses. The first of these poems was the Nautica (1685), a work in eight books on the construction of ships and Mediterranean and transatlantic seafaring. The work was followed by the ten books of the Halieutica (1689), dedicated to the description of various types of fish and methods of fishing. In 1697, Giannettasio published the Bellica, fifteen books on different techniques of warfare (such as battle strategies, weapons, fortresses), and, finally, the Naumachica (1697), five books on warfare at sea. All of Giannettasio's didactic poems were extremely successful: the Nautica, for example, was published in four editions (Naples 1685, 1686, 1692, and 1715), and copies of his works can still be found in major European libraries. ${ }^{7}$

These works initiated a very particular form of Jesuit literature, one which can be described as Virgilian-style didactic poetry. In Naples, at least two poets seem to have imitated Giannettasio's didactic poems: Francesco Eulalio Savastano (1661-1717) and Camillo Eucherio de Quinzi (1675-1733). At the

proper - certainly a quite suitable theater in the future whose author and architect was the very same]. For the church, cf. Michele Errichetti, S.J., "La Cocumella," Societas 5-6 (1978): 65-70; for the whole complex, see Filippo Iappelli, "Da residenza gesuitica a grande albergo: La Cocumella," Societas 5-6 (2003): 247-57.

4 For Giannettasio's writings, cf. Schindler, "Nicolò Partenio Giannettasio," 146-47.

5 For this work, see Elisabeth Klecker, “Liebe verleiht Flügel': Ein neulateinisches Epos über die Missionsreisen des Heiligen Franz Xaver," in: Franz Xaver-Patron der Missionen: Festschrift zum 45o. Todestag, ed. Rita Haub and Julius Oswald, S.J., Jesuitica 4 (Regensburg: Schnell \& Steiner, 2002), 151-81; Florian Schaffenrath, "Ein angekündigtes Columbus-Epos im Xaverius viator: Niccolò Giannettasios Verweise auf frühere und kommende Werke," Antike und Abendland 53 (2007): 178-89.

6 Cf. Claudia Schindler, "Vitreas crateris ad undas: Le egloghe piscatorie di Nicolò Partenio Giannettasio (1648-1715)," Studi umanistici piceni 23 (2003): 293-304.

7 Schindler, "Nicolò Partenio Giannettasio," 147. 
beginning of the eighteenth century, Savastano composed four books on medicinal herbs, ${ }^{8}$ and de Quinzi published six books on the thermal baths of the island of Ischia. ${ }^{9}$ Giannettasio mentions Savastano's poem in his Naumachica, ${ }^{10}$ and de Quinzi alludes explicitly to the poetic works of Giannettasio." The relationship between Giannettasio and Tommaso Strozzi (1631-1701) and his poem on chocolate (De mentis potu seu de cocolatis opificio, Naples, 1689) is not clear, although its poetic concepts are quite close to Giannettasio's and the latter mentions chocolate and its therapeutic value within his Annus eruditus. ${ }^{12}$ The Croatian poet Bernardo Zamagna's (1735-1820) didactic poem on airships, the Navis aeria, which was published in Ragusa (modern-day Dubrovnik) in 1768, uses Giannettasio's Nautica as a model but belongs to a different neo-Latin tradition, which starts in the middle of the eighteenth century and focuses on technical and philosophical subjects. ${ }^{13}$

Francisci Eulali Savastani Botanicorum seu institutionum rei herbariae libri IV (Naples: Novelli de Bonis, 1722).

9 Camillo Eucherio de Quinzi, Inarime seu de balneis Pithecusarum libri vi (Naples: Felix Mosca, 1726). For an Italian translation (with a long introduction), see Camillo Eucherio de Quinzi, Inarime (De balneis Pithecusarum), trans. Raffaele Castagna (Ischia: La Rassegna d'Ischia, 2003). See also Gennaro Xavier Gamboni, S.J., Ischia e il suo poeta, Camillo Eucherio Quinzi S.J. (Naples: Stiped, 1952); Antonietta Iacono, "Gli umanisti e le acque di Ischia," in Intorno ai Campi Flegrei: Memorie dell'acqua e della terra (Naples: Grimaldi, 2011), 745.

10 Giannettasio, Naumachica (Naples: Raillard, 1715), 19: Ipse vel in primis Vati charissimus olim / ad Medicas capiet felix Eulalius Herbas.

11 De Quinzi, Inarime, book 4 (Naples: Felix Mosca, 1726), 175: Nec sola suos det Olympica vates / acta, Sophocleo tractent qui barbiton oestro: / et varios plectro cursus, pelagique recursus, / et piscandi artes, et Martia praelia discant / seu campo, seu velivolis tenenda carinis [Not just the Olympian shores shall provide their poets, that they may play the lyre with a Sophoclean frenzy and with a plectrum (quill) teach the various departures and returns (on the sea), the arts of fishing and the Martian battles to be fought either on land or on sail-bearing ships].

12 Tommaso Strozzi, S.J., Poëmata varia (Naples: Parrino e Muzio, 1689); Haskell, Loyola's Bees, 82-117; Cf. also Haskell, "Poetry or Pathology? Jesuit Hypochondria in Early Modern Naples," Early Science and Medicine 12 (2007): 187-213; Haskell, "Bad Taste in Baroque Latin? Father Strozzi's Poem on Chocolate," in Tous vos gens a latin: Le latin, langue savante, langue mondaine (XIVe-XVIIe siècle), ed. Emmanuel Bury (Geneva: Droz, 2005), 429-38. As the poem is dedicated to the last Medicean grand duke of Tuscany, Gastone de' Medici (1671-1737), it seems to have a Florentine rather than a Neapolitan context. On the other hand, Strozzi mentions several Neapolitan personalities, such as Archbishop Ascanio Filomarino (1583-1666), who also plays a certain role in Giannettasio's poems.

13 Edition and translation of the poem by Diane Bitzel, Bernardo Zamagna. Navis aeria. Eine Metamorphose des Lehrgedichts im Zeichen des technischen Fortschritts, Studien zur klassischen Philologie 109 (Frankfurt am Main: Peter Lang, 1997). 
With his poems, Giannettasio thus initiated one of the literary microcultures (or, as Yasmin Haskell calls it, "Jesuit microtraditions"), ${ }^{14}$ which are typical of neo-Latin literature, and especially neo-Latin Jesuit literature, but which have thus far been insufficiently explored owing to the sheer amount of material. This chapter consequently seeks to highlight some intra- and extra-literary aspects of this specific and distinctive Neapolitan Jesuit microculture in order to explain the great popularity of Giannettasio's poems in seventeenth-century Europe.

The neo-Latin didactic poetry of Giannettasio and his Neapolitan confreres at the end of the seventeenth century features two themes, both of which played a role in their success: the local references to the Bay of Naples and its literary and cultural traditions, and the Jesuit doctrine and networks. With regard to the former, Giannettasio's poems, as well as the poems of his poetic successors, show conspicuous connections to the city of Naples and its surroundings, the Bay of Naples and the Sorrento Peninsula. Giannettasio presents the city of Naples, and the bay area adjacent to Mount Vesuvius, as a mythological landscape, an area soaked with cultural and ecclesiastical heritage, ${ }^{15}$ as an ideal area for poetical studies. Giannettasio viewed Naples as the center of poetic inspiration. This role was indebted to the city's history: Naples was founded by the Siren Parthenope; thus, Giannettasio calls his home city patria Siren or Siren Parthenope, and connects it with three other Sirens, which seem to have sprung out of his poetic imagination: Megare, Aegle, and Olympia. ${ }^{16}$ These Sirens assume the role of the Muses, as they provide him with poetic inspiration. On the other hand, the term Olympides (daughters of the Olympian Zeus), which he uses as a synonym for Muses, ${ }^{17}$ reminds the reader of the Siren Olympia. Aside from these constructions

14 Haskell, Loyola's Bees, 6.

15 E.g., Giannettasio, Halieutica, 25: Haec eadem Musas, et doctas extudit artes, / Campanoque sonum dedit aere; et pyxida Nautis / protulit, et tenui telas intexuit auro. / Haec vates lauro insignes, rubroque galero / Romuleos patres, clarosque Heroas in armis, / et tot Pontifices tulit [...] [The very same produced the Muses and the learned arts, generated sound with the Campanian ore, discovered a small box for seamen and (inter)wove delicate gold threads. She produced poets famous for their laurels, Roman fathers with red glimmering helmets, and famous heroes in arms and as many priests].

16 Giannettasio, Naumachica, book 5, 80: atque coronatas ad littora vertere proras, / quo me festivis compellant vocibus illinc / Parthenope, Megareque, et Olympia dulcis, et Aegle [and to turn the wreathed bows to the shores whereto (and from where) Parthenope, Megare, sweet Olympia, and Aegle invite me with fine voices]. The names of Megare, Olympia, and Aegle do not stem from the classical tradition.

17 Giannettasio, Piscatoria, ecloga 1.36 (with note). 
based upon the heritage of classical mythology, Giannettasio presents Naples as the home city of two famous neo-Latin poets, Giovanni Pontano (1429-1503) and Jacopo Sannazaro (1458-1530), whose Manes he mentions explicitly in his Piscatoria when alluding to Sannazaro's tomb in the Santa Maria del Parto church, not far from Sannazaro's former home, the Villa Mergellina. ${ }^{18}$ But in the first place, Naples is the city of Virgil, who, according to the late antique biographic tradition, also has his tomb there, not far from Sannazaro's tomb, near the Santa Maria di Piedigrotta church, ${ }^{19}$ and wrote his Georgics during an "ignoble leisure time at Naples" (ignobile otium), as he declares in the sphragis of this work. ${ }^{20}$

Giannettasio and his other Neapolitan colleagues made use of these "environmental" circumstances and advantages to justify their decision to use didactic poetry as a literary form and to stylize themselves as Virgil's natural heirs. But they were not the first to adopt the neo-Latin didactic poetry on the basis of Virgil's Georgics. In the fifteenth century, Italian humanists had discovered that the "classical" Roman didactic poetry, especially Virgil's Georgics, could be used as an instrument to present agricultural themes and themes of natural science. In the late seventeenth century, Pontano's Urania (1476), his poem De hortis Hesperidum (completed c.150o), as well as the Veronese physician Girolamo Fracastoro's (c.1478-1553) poem on syphilis (1530), had become canonic texts, which Giannettasio and Strozzi knew very well. ${ }^{21}$ Concerning the Jesuit tradition of Virgilian-style didactic poetry, the Neapolitans could also refer to the Hortorum libri of the French Jesuit René Rapin (1621-87),

18 E.g., Giannettasio, Piscatoria, ecloga 1.38: Synceri applaudunt, Manes Manesque Maronis; Schindler, "Vitreas crateris ad undas," 298. As Sannazaro was buried in the church Santa Maria del Parto, which he had erected himself, Giannettasio wanted to be buried in his church, Santa Maria del Gesù.

19 On the location of Virgil's grave, cf. John Webster Spargo, Virgil the Necromancer (Cambridge, MA: Harvard University Press, 1934); Joseph B. Trapp, "The Grave of Vergil," Journal of the Warburg and Courtauld Institutes 47 (1984): 1-31; Michael C.J. Putnam and Jan M. Ziolkowski, The Virgilian Tradition: The First Fifteen Hundred Years (New Haven and London: Yale University Press, 2008). Giannettasio discusses the location of Virgil's grave in his Historia Neapolitana (Naples: Michele Luigi Muzio, 1713), 6, and in the Hyemes Puteolanae (Naples: Raillard, 1722), 170-71.

20 Virgil, Georgics, 4.563-66: illo Vergilium me tempore dulcis alebat / Parthenope studiis florentem ignobilis oti, / carmina qui lusi pastorum audaxque iuventa, / Tityre, te patulae cecini sub tegmine fagi [At this time sweet Parthenope nourished me, Virgil, flourishing in the pursuits of obscure peace; who played with shepherds' songs, and, in my youth sang boldly of you, Tityrus, in the shade of the wide-spreading beech-tree]. 
a poem on French horticulture, which was published in Paris in 1675 . Giannettasio, who curated a Neapolitan edition of Rapin's poem in $1685,{ }^{22}$ adored his poetic predecessor and mentions him in the proem to the fourth book of his Nautica. ${ }^{23}$ Rapin also found didactic successors among the French Jesuits: at the end of the seventeenth and the beginning of the eighteenth century, French Jesuits wrote didactic poems on a wide range of subjects, such as music, dreams, coffee and tea, and the education of children, a great number of which are collected in the 1749 edition of François Oudin $\left(1673^{\left.-175^{2}\right)} \cdot{ }^{24}\right.$

Yet the didactic poems of Giannettasio and his successors seem to present a distinct form of neo-Latin didactic poetry which departs considerably from the "French" tradition. By placing their didactic poems in the Neapolitan environment and recalling the mythological and literary traditions of classical antiquity, which are exclusively connected with the Bay of Naples, they present themselves as the legitimate heirs of Virgil. While the French Jesuits in their didactic poems could refer to Virgil as "the classic of all Europe," the Neapolitans could rely on a strong local tradition and invoke the Sirens as well as the manes Maronis - the soul of the dead Virgil—and the Campania felix, the fertile landscape adjacent to Mount Vesuvius, as a fountain of poetical inspiration.

Giannettasio, in particular, highlights his indebtedness to Virgil as his Neapolitan predecessor. The openings of his didactic poems are closely linked with the proem of Virgil's Georgics, whose syntactical structure the baroque poet maintains: for example, the Nautica are opened by Quae veniant nemora apta mari, quo sydere pinus / Caedere, [...] / Conveniat: [...] / Hinc canere [...] incipiam (I shall begin to sing of [...] which trees may be suitable for the sea,

22 René Rapin, Hortorum libri IV, new ed. (Naples: Raillard, 1685).

23 Giannettasio, Nautica, book 4 (Naples: Raillard, 1715), 113-14: Quod si aliquis forsan, ruris qui nuper amore / captus odoratis halantes floribus hortos, / et nemora, et fontes cecinit, croceisque corollam / floribus aeternam sibi texuit, alta Maronis / tendentis coelo vestigia pone secutus, / atque per ora virum plausu volat undique victor: / Jam nunc bella paret, Magnique illustria Regis / facta, et victrices etiam contexere palmas / carmine Maeonio. Felix, cui numine multo / se penitus totum inspirat per pectora Phoebus: / atque opus in tantum properat deus [If perhaps anyone, recently smitten by a love for rural life, sang of gardens smelling of fragrant flowers and woods and springs, wreathed himself an eternal crown of saffron-colored flowers, following the deep tracks of the skywards striving Maro and, universally applauded as a conqueror, flies through the mouths of men, he may already intend to combine wars, illustrious deeds of a great king, and the victor's palms in a Homeric poem. Lucky whom Phoebus inspires with much divine might so thoroughly in his heart: God quickens such a great work].

24 François Oudin, Poemata didascalica, primum vel edita vel collecta studiis, ed. Joseph Oliveto, 3 vols. (Paris: Au. Delalain, 1813). 
under which star one should [...] fell the pine), which is a close imitation of the opening of Virgil's Georgics: Quid faciat laetas segetes, quo sidere terram / Vertere, Maecenas, ulmisque adiungere vites / Conveniat [...] / Hinc canere incipiam (I shall begin to sing of what causes the crop to be abounding, under which star one should plow the earth, Maecenas, and fasten vines to elms).

In a similar way, the closing lines of the Nautica allude to the sphragis of the Georgics. The same observation can be made for the other Neapolitan didactic poets. Prominent narrative passages of the Georgics, such as the myth of Aristaeus or the Corycian gardener, which are often imitated in neoLatin didactic poetry, ${ }^{25}$ also reappear in Giannettasio's didactic poems, with the aim of multiplying, surpassing, rivaling, and even correcting the classical predecessor. In the Halieutica, the famous Laudes Italiae of Virgil's Georgics are transformed into Laudes Campaniae, ${ }^{26}$ where the poet celebrates the idyllic landscape and the fertility of the region adjacent to Vesuvius. Giannettasio's successor, Savastano, employs a similar literary technique in the third book of his Botanicorum libri, but his Laudes Campaniae not only follow Virgil's Laudes Italiae but also the Laudes Campaniae of his literary Neapolitan predecessor. $^{27}$

Giannettasio's competitive attitude towards Virgil is also evident in his adoption of the academic name "Parthenius," which at the same time is an allusion to the mythological name of Naples, Parthenope, as well as the tradition of the "virgin Virgil," Vergilius Parthenius, of the late antique biographical tradition.

Giannettasio, the "new Virgil," seems to have been a kind of literary trendsetter who revitalized Virgilian-style didactic poetry at Naples in the 168os. But how do the secular topics of his poems, his "archaizing" poetic concepts, and the manifold references to Virgil and the Bay of Naples fit into the major goals of the Society of Jesus? Observing the particularities of their literary technique, Giannettasio's poems as well as the other poems of the Neapolitan literary

25 Cf. Schindler, "Nicolò Partenio Giannettasio," 157-60; Heinz Hofmann, "Aristaeus und seine Nachfolger. Bemerkungen zur Rezeption des Aristaeus-Epyllions in der neulateinischen Lehrdichtung," Humanistica Lovaniensia 52 (2003): 367-69; Ruth Monreal, "Vergils Vermächtnis: Die Gartenpraeteritio in den Georgica (4,116-148) und Typen ihrer Rezeption im neulateinischen Lehrgedicht," Humanistica Lovaniensia 54 (2005): 1-47.

26 Halieutica, book 1, 24-25.

27 Savastano, Botanicorum libri (Naples: Novelli de Bonis, 1712), book 3, 88-9o. De Quinzi's poem has Laudes Aeneariae (De Quinzi, Inarime [Naples: Felix Mosca, 1726], 104-7), in which the poet says that the world's other baths, except for the Aquae Carolinae, will never reach the healing power of the baths of Ischia. 
microculture, could strike the modern reader as a highly intellectual game, written, as the poet himself declares, during his time of leisure on the peninsula of Sorrento; an intellectual game which, in an extremely referential way, makes use of the Neapolitan environment, its local traditions, and the spirit of the famous Virgil to vitalize the ancient literary genre of didactic poetry. I argue that Giannettasio's learned poems were not only efficient instruments to spread Jesuit doctrine but that his Virgilian-style didactic poetry, on a certain level, was also a far more subtle means to advertise Jesuit ideas than any theological treatise. For this reason, it is important to take a closer look at the contents and topics of Giannettasio's poems.

As has been mentioned, the subject matter of Giannettasio's poems is exclusively secular. To a modern reader, seafaring, fishing, and warfare as topics of neo-Latin poems may sound odd. But in effect, these topics are more closely connected to Giannettasio's cultural surroundings than one might expect. Seafaring, fishing, and warfare require several natural and technical sciences such as mathematics, physics, zoology, astronomy, geography, and engineering. They thereby match the scientific interests of the Jesuits, who extended their influence to the field of education in the seventeenth and eighteenth centuries through their global system of schools and universities. ${ }^{28}$ As scholars have pointed out, these activities fit perfectly into the theological concept of the Society. As an "active prayer,"29 learning obtained a status equivalent to the spiritual exercises, as is testified by the Jesuit Constitutions (4.4.2): Litteris dare operam, quae syncera cum intentione divini servitii addiscuntur, et quodammodo totum hominem requirunt, non minus, quam in illis versari tempore studiorum, immo magis Deo ac Domino nostro gratum erit (To devote oneself to learning, which they acquire with the sincere intention of divine service and in some way require the entire man, is not less, no on the contrary, it is even more welcome to God our Lord than to dwell on those religious matters during the time reserved for studying).

The Jesuits' scientific studies in engineering, mathematics, and the natural sciences were designed for the major glory of God, ad maiorem Dei gloriam. As the human intellect's spirit of research and its inventiveness testify to the creative power of God - who provided humans with intelligence in order to make use of it-Jesuit scientific research sought to use people's intellectual capacities to achieve this goal as well as adoring God's creation in an adequate

28 On the Jesuits' scientific interests, cf. Steven J. Harris, "Transposing the Merton Thesis: Apostolic Spirituality and the Establishment of the Jesuit Scientific Tradition," Science in Context 3 (1989): 29-65. 
manner. ${ }^{30}$ By choosing scientific topics, the Neapolitan Jesuits met the requirements of their order. ${ }^{31}$

Far more complicated is the question of why Giannettasio, to promote his scientific topics, was so successful when he preferred the genre of didactic poetry to a treatise in prose. Although a sense of local patriotism certainly influenced his decision, it should also be noted that the Jesuits viewed Virgil as an authoritative author. In the seventeenth century, the French Jesuit Charles de la Rue (1643-1725), as well as his Spanish confrere Luis de la Cerda (1558-1643), published voluminous commentaries on Virgil's entire work. ${ }^{32}$ The fact that the Georgics offered an ideal pretext "for figuring and affirming the Ignatian wedding of action and contemplation," as Haskell suggests, ${ }^{33}$ should also be taken into account. Nevertheless, to understand the motifs of Giannettasio, and his successors, I will now turn to another aspect of his poetry.

Giannettasio was a well-trained and erudite man with a stupendous amount of knowledge on different fields of knowledge, but he was no more of an expert on fishing, seafaring, and warfare than any contemporary erudite. In his poems, he did not include his own breathtaking insights, but relied on scientific treatises, which he quotes explicitly in the prosaic forewords to his poems or in explanatory footnotes. ${ }^{34}$ Although the pieces of information he gives are based on accurate research, his didactic poems are not "schoolbooks" in a strict sense. The instructions for shipbuilding in the second book of the Nautica, for example, are incomplete, and the author's geographical remarks are unreliable. ${ }^{35} \mathrm{In}$ the preface to the Nautica, Giannettasio informs his readers that these "gaps" are not a result of his negligence, but of an elaborated poetic concept. He admits that he has left out the mathematical aspects of navigation, for such technical details would not match the elegance of his poem: Cum nullam carmini decorem allatura essent. ${ }^{36}$ The "didactic" passages of the poem sometimes

\footnotetext{
$30 \quad$ Cf. ibid., who also speaks about a "sanctification of learning."

31 Haskell, Loyola's Bees, 13-14.

32 Charles de la Rue, $P$. Vergilii Maronis opera interpretatione et notis illustravit, 2nd ed. (Paris: Simon Bénard, 1682); Luis de la Cerda, P. Vergilii Maronis Bucolica et Georgica, argumentis, explicationibus, notis illustrata, auctore, 3 vols. (vol. 1, Frankfurt am Main: Zacharius Palthenius, 1608; revised ed.: Lyon: Horatius Cardon, 1618; vol. 2, Lyon: Horatius Cardon, 1612 and Frankfurt am Main: Zacharius Palthenius, 1613; vol. 3, Lyon: Horatius Cardon, 1617 [reprints]).

33 Haskell, Loyola's Bees, 15.

34 Cf. Schindler, "Nicolò Partenio Giannettasio," 149. Strozzi adds explanatory footnotes to his poem, and Savastano and de Quinzi adopt this technique.

35 Schindler, "Nicolò Partenio Giannettasio," 151-53.

36 Giannettasio, Nautica, "Praefatio," 47.
} 
give the impression of a "Wunderkammer," a baroque collector's closet, who gathers mirabilia mundi from the remotest parts of the earth. ${ }^{37}$ As Haskell has shown, Giannettasio's Halieutica tend to be more "poetry of wonder" than a scientific text. ${ }^{38}$ The same is true, mutatis mutandis, for the Nautica. His literary technique, derived from the antique models, also plays an important role. Geographical places, natural phenomena, and zoological curiosities are arranged in highly sophisticated catalogs, and technical equipment for seafaring is described in extended ecphraseis, which challenge not only the author's but also the reader's knowledge of Latin.

Giannettasio represents himself in the Nautica as well as in his other poems as a poet rather than a scientist. Aesthetic aspects are prioritized over scientific accuracy. The overwhelming success of his didactic poetry, especially of the Nautica, seems to be based on this concept. While Jesuit scientific research tended to be marginalized at the end of the seventeenth century, ${ }^{39}$ the Neapolitan poet and his successors developed an innovative form to communicate technical knowledge: a form that explicitly declares it is not engaging with current scientific discourses, but which presents knowledge in an aesthetic, readable, and even entertaining manner and provides pieces of information without asking too much of its reader. ${ }^{40}$ The idyllic landscape of the Bay of Naples and the strong relationship to Virgil and his neo-Latin didactic successors underline the aesthetic aims of Giannettasio's poems. Not meant to rival current scientific discourses, the poems envisage a readership of aristocratic intellectuals, the community of virtuosi and cognoscenti, who were in close contact with the Jesuits during the seventeenth century. These intellectuals, who show up in the dedicatory prefaces to the poems, seem to have been particularly susceptible to the Jesuits' new approach to communicating

37 Haskell, Loyola's Bees, 79-81. For the baroque Wunderkammer, cf. Dieter Pfister, Die Kunstund Wunderkammer in Praxis und Theorie: Aspekte des manieristischen Universalsammlungswesens (Basel, 1982); Steffen Siegel, "Die 'gantz accurate' Kunstkammer: Visuelle Konstruktion und Normierung eines Repräsentationsraums in der Frühen Neuzeit," in Visuelle Argumentationen: Die Mysterien der Repräsentation und die Berechenbarkeit der Welt, ed. Horst Bredekamp and Pablo Schneider (Munich: Wilhelm Fink, 2006), 157-82.

38 Cf. Haskell, Loyola's Bees, 70.

39 Cf. William B. Ashworth Jr., "Catholicism and Early Modern Science," in God and Nature: Historical Essays on the Encounter between Christianity and Science, ed. David C. Lindberg and Ronald L. Numbers (Berkeley: University of California Press, 1986), 136-66, 154-6o.

40 As Haskell (Loyola's Bees, 101-17) has shown, Francesco Eulalio Savastano's Botanicorum libri have a more scientific approach. Perhaps this is why they were less successful than Giannettasio's poems. 
knowledge about the wonders of the world. Reinventing the ancient but wellestablished genre of didactic poetry, Giannettasio strengthens this literary form as a unique feature of Jesuit poetry.

As for Giannettasio's Nautica, another aspect is even more important. As well as being a distinct form of Neapolitan neo-Latin poetry, this poem is also a distinct piece of Jesuit literature, an important contribution to the seventeenthcentury Jesuit intellectual culture. When Giannettasio assumed the academic name Parthenius, he not only referred to Virgil and to the city of Naples but also to the Virgin Mary, whom he himself dubbed Parthenia genetrix in the dedicatory inscription of his church, La Cocumella in Sorrento, which reads: Partheniae genetricivates Parthenius. The secular appearance of the poem and the various allusions to classical antique mythology and to Neapolitan Virgil tend to disguise the fact that the secular didactic is soaked with Jesuit values and doctrine. This observation is less surprising than it might sound. It is quite obvious that in a piece of poetry composed by a member of the Society of Jesus, nothing is written that contradicts the rules and regulations of the Society, and hence Jesuit poetry, in Haskell's words, tends to present a world that is "informed, if not forged by the values of the Society of Jesus." ${ }^{\text {"1 }}$ What is interesting about this observation is that Giannettasio's Nautica communicate Jesuit doctrine on different levels. In the prosaic preface of this poem to the reader, Giannettasio points out that seafaring is a moral discipline (moralis disciplina) which could be learned more easily by examples than by bare instructions. ${ }^{42}$ Several copies of the Nautica's second edition are illustrated by nine copperplate engravings by François de Louvemont (1648-?) on the basis of patterns by Francesco Solimena (1657-1747). ${ }^{43}$ These engravings do not illustrate technical aspects of shipbuilding and seafaring, as one might expect. On the contrary, they depict motifs from the mythological and autobiographical passages of the poem, such as the launch of Hiero's state barge (book 2), Nisus being instructed about magnetic deviations (book 3), Giannettasio's farewell to Naples (book 5), his rescue from a storm at sea (book 6), and Columbus's ships crossing the ocean (book 8). As in emblematic art, the

41 Haskell, Loyola's Bees, 15.

42 Giannettasio, Nautica, "Praefatio," 47.

43 For the illustrations, see Giuseppe De Nitto, "L'arte tipografica napoletana del Seicento," in Seicento Napoletano: Arte, costume e ambiente, ed. Roberto Pane (Milan: Edizioni di comunità, 1984), 479; Filippo Iappelli, S.J., "Gesuiti e Seicento Napoletano—III," Societas 34 (1985): 110-13. For the relationship between Giannettasio and Solimena, cf. Harold Samuel Stone, Vico's Cultural History: The Production and Transmission of Ideas in Naples (Leiden: Brill, 1997), 20-23. 
illustrations are furnished with a caption showing a motto from the book they illustrate: Coeptis insistere multum est (It is a great deal to persist in [one's] undertakings) for the first book; Quae non miracula rerum ingenium facit acre manusque operosa magistri (What kind of miracles are not achieved by a keen intellect or a teacher's laborious hand) for the second; and Principio venerare deos, quorum aequora curris (First of all venerate the gods whose seas you are traveling) for the fourth. These maxims are not exclusively bound to the subject of the Nautica. On the contrary, they can be read as mottos for the Jesuit life.

Giannettasio's "Jesuit" attitude can be observed throughout the entire poem. In the proem to the first book, the poet invokes the Jesuit missionary in the East, Francis Xavier (Saberides), as his patron saint. In the Nautica, Xavier replaces Octavian, who had been introduced as Virgil's patron in the proem of the first Georgic. Furthermore, the co-founder of the Jesuit order officiates as inspiration for the poet as well as an authority on all matters of seafaring. ${ }^{44}$ The sailors, before setting sails, should therefore not only say a prayer to the Holy Trinity and to Virgin Mary but also to Francis Xavier, ${ }^{45}$ he is also to be

44 Giannettasio, Nautica, 50: At tu, qui Superos inter spatiaris Olympo, / SABERIDE, mihi dexter ades: tu dius Apollo / magnam Vati animam, et divini carminis oestrum / inspira; nostrisque volens allabere coeptis. / Nam te, nec fallor, magnarum numen aquarum, / rectoremque maris, tempestatumque potentem / Gangaridae quondam dixere, et creditus Indis / Oceani immensi magnus Deus, humida parent / Neptuni cui regna, vagique per aera nimbi, / et se pacato submittunt murmure venti. /Sed quamvis (tibimentitum non fingimus ultro / numen, et immeritos aris adolemus honores) / non deus Oceani, verum tibi gurgitis alti / imperium Pater Omnipotens dedit, ut tua nautae / numina rite colant: placidos tu tollere nutu, / turbatosque potes nutu componere fluctus [You, however, Xavier who you walk among the heavenly powers in heaven, help me graciously: as a divine Apollo grant great inspiration to the poet and the enthusiasm of a divine poem and join our undertaking willingly. For the inhabitants of the Ganges's banks called you once-and I am not mistaken in thisdivinity of the great seas, mighty director of the seas and tempests and by the Indians you were believed to be the great god of the immense ocean whom the watery kingdoms of Neptune and the clouds, roaming the sky, obey and to whom the winds submit with a pacified murmur. Yet even if you are not the god of the ocean (we do not invent a madeup divinity for you and bring undeserved honors as offerings on altars), the omnipotent father gave you dominion of the deep sea so that the seamen worship your divine/ supreme authority duly: you are able to disturb placid waves with a nod and (also) calm agitated seas with a nod. And finally, Palinurus, call the oceans influential divine/supreme authority of the great Xavier. He overwhelms tornadoes with a mighty right and appeases hearts and minds].

Ibid., 117 . 
invoked during a typhoon together with other divine authorities. ${ }^{46}$ These instructions are confirmed by the author's own experience: traveling from Sorrento to Egypt, the author reports, he was hit by a terrible storm at sea. This "autobiographical" sea-storm is transformed into a literary sea-storm, as Giannettasio narrates it by using traditional elements of sea-storms from pagan and Christian Greco-Roman literature: uproar of the elements, desperation of the passengers, encouraging words of the ship's helmsman..$^{47}$ But there is something distinct about Giannettasio's sea-storm. As a Jesuit, he prays to Xavier, who appears immediately and appeases the storm; Giannettasio then makes a vow to praise Xavier in a poem, which the saint graciously accepts. ${ }^{48}$ The numerous references to Xavier show that, for Giannettasio, religiosity surpasses technical progress. At the same time, by referring to Xavier, he also emphasizes the fact that it is the Jesuit co-founder whom God established as the sailors' patron.

In addition to this emphasis on Xavier's role in seafaring, many of the instructions in the Nautica were drawn from the Jesuit spirituality, with obedience, discipline, and labor, as well as piousness, being essential for successful seafaring. Giannettasio's instructions sometimes correspond verbally with the summary of the Jesuit Constitutions. As the poet points out, sailors never have to be without employment during the voyage: Hic sed praecipiam queis artibus otia pubes / Interea vitet: semper vitanda Magistro, / Et vitanda mari in medio sunt otia Nautis:/ Quippe animi robur frangunt, viresque remittent (Yet here I shall teach how the men may avoid idleness in the meantime: the captain always has to avoid lulls/leisure and the seamen have to avoid idleness in the middle of the ocean. For they break the strength of mind and will sap the physical strength). ${ }^{49}$ This reads like a versification of rule 44 from the Summarium Constitutionum (Regulae Societatis Jesu, Antwerp 1635, 21): Otium vitandum. Omnes, quamdiu corpore bene valent, in spiritualibus vel exterioribus habeant in quo occupentur, ne otium malorum omnium origo, [...], Domi nostrae locum habeat (Idleness has to be avoided: everyone shall have something among spiritual or secular matters to occupy himself as long as he is physically able to, so that idleness, the origin of all evil, [...] has no place in our house). .0

46 Ibid., 231: Ac demum Oceani praesentia Numina magni / SABERIDAE, Palinure, voca: premit ille potenti / dextra Typhones, animosque, et pectora mulcet.

47 Ibid., $173-75$.

48 Ibid., 175 .

49 Nautica, 130.

5o Cf. also Constitutiones, 3.1.6. 
Connecting the subject matters of his poetry with Jesuit rules, in his Nautica Giannettasio can take advantage of the fact that "ship" and "seafaring" are traditional metaphors for the church and faith, and he exploits these metaphorical subtexts. Diligence (diligentia), for example, is an important Jesuit value, ${ }^{51}$ and thus, in the first book of his poem, Giannettasio stresses the fact that the shipbuilder has to select the wood for his ships most carefully. But soon the diligent shipbuilder will be rewarded, as he will construct a ship that will easily brave all storms. ${ }^{52}$ As well as practical advice for the craftsman, these verses can be read as an instruction for true faith, which should be based upon a solid fundament, for the faithful will then be able to cope with the storms of life. To a certain extent, the author's own salvation from the sea-storm, aside from its biographical impact, can be regarded as a metaphor for his "conversion" to the Society of Jesus. The Nautica can therefore be read according to the quattuor sensus scripturae (the four kinds of meaning of the scripture): literally, as a source for nautical details, allegorically, as a statement on faith, ethically, as a guideline for right behavior, and, anagogically, as an instruction for further actions.

This interpretation of the Nautica according to the quattuor sensus scripturae is consistent with the fact that Giannettasio's most important literary model, Virgil, had been read allegorically since late antiquity. ${ }^{53}$ But another aspect should also be stressed in this context. Apart from the allegorical lectures of his poem, late antique church fathers tended to regard the Roman national poet as a Christian author and the fourth eclogue as an announcement of Christ's birth; ${ }^{54}$ imitating Virgil's poetry therefore served as an instrument

\footnotetext{
$51 \quad$ Cf. Ibid., 4.16.5.

$5^{2} \quad$ Nautica, 51.

53 Cf. Harrison C. Coffin, "Allegorical Interpretation of Vergil, with Special Reference to Fulgentius," Classical Weekly 15 (1921/22): 33-35.

54 For Christian adaptations of Virgil, cf. Harald Hagendahl, Latin Fathers and the Classics: A Study on the Apologists, Jerome and Other Christian Writers (Gothenburg: Almqvist och Wiksell, 1958); Pierre Courcelle, Lecteurs païens et lecteurs chretiens de l'Eneide, 2 vols., Mémoires del Academie des inscriptions et des belles-lettres n.s. 4 (Paris: De Boccard, 1984); Eberhard Heck, "Vestrum est-Poeta noster: Von der Geringschätzung Vergils zu seiner Aneignung in der frühchristlichen lateinischen Apologetik," Museum Helveticum 47 (1990): 102-20. For allegoric readings in the Renaissance, cf. Craig Kallendorf, In Praise of Aeneas: Virgil and Epideictic Rhetoric in the Early Italian Renaissance (Hanover: University Press of New England, 1989), 101. On the fourth eclogue, see, e.g., Lactantius, Divinae institutiones, 7.24.11; Vinzenz Buchheit, "Vergil als Zeuge der natürlichen Gotteserkenntnis bei Minucius Felix und Laktanz," Rheinisches Museum 139 (1996): 254-59.
} 
to uncover its alleged Christian elements. Giannettasio, who seems to follow this concept, reinterprets his Neapolitan predecessor according to the Society's goals. At the beginning of the seventh book of the Nautica, he announces that in India, at the mouth of the River Ganges, he will construct a marble church, whose doors will be decorated with reliefs molded from silver, gold, and ivory. ${ }^{55}$ Although Giannettasio, as has been said, came forward as a "real" architect, his Indian church is not a real, but a virtual church. The reliefs on its doors are products of Giannettasio's poetic imagination. This becomes clear from his description, where Giannettasio alludes to a prominent Virgilian praetext. In the proem of the third book of the Georgics, the poet announces that he will build a temple at the shore of the Mincius River, and that the temple's doors will be decorated with depictions of Octavian's triumph. ${ }^{56}$ The Jesuit commentary of Juan Luis de la Cerda interprets this triumph as a triumphus poeticus. ${ }^{57}$ Imitating Virgil, Giannettasio strengthens this allegorical (and even poetological) interpretation. He transfers the sacral building (templum) from Italy to India, and its doors no longer represent the triumph of Octavian, but the successful eastern Jesuit mission. Despite the manifold verbal and syntactical allusions, the Jesuits' triumphi surpass the triumph of Octavian - and they establish the Jesuit order as a legitimate heir of the Roman Empire. At the same time, Giannettasio, by presenting his Neapolitan predecessor in this way, denies other institutions any Roman heritage.

In this context, another transformation of a Virgilian model should be pointed out. At the end of the second book of the Nautica, which mainly deals with how ships should be launched, the author inserts an aetiological myth, ${ }^{58}$ which is opened by the following verses (83): At si quem forte ars prorsus defecerit omnis, / Nec, quo sylva modum pelago mittatur habebit:/ Tempus et Ortygii memoranda inventa magistri / Pandere, quoque modo turritam mole carinam / In mare deduxit pueri manus. Altius omnem / Expediam antiqua revocans ab origine famam (But when perhaps all arts will have deserted someone and he will have no manner to launch a ship, it will be time to spread out the memorable inventions of Ortygia's teacher and in which manner the hand of a boy

\footnotetext{
$55 \quad$ Nautica, 195-96.

$56 \quad$ Verg., Georg., 3.26-33.

57 De la Cerda, $P$. Vergilii Maronis Bucolica et Georgica, argumentis, explicationibus, notis illustrata, auctore, 1:348.

$5^{8}$ For this narration, cf. Claudia Schindler, "L'invenzione della realtà: Alcuni brani biografici e storici nei poemi didascalici di Nicolò Partenio Giannettasio (1648-1715)," Studi umanistici piceni 22 (2002): 247-48.
} 
conveyed a ship with towers to the sea. I shall tell the entire story at greater length beginning with its ancient origin).

These verses show literal parallels with the introductory verses of the socalled Aristaeus-myth in the fourth book of Virgil's Georgics (4:281-86): Sed si quem proles subito defecerit omnis, / nec genus unde novae stirpis revocetur habebit, / tempus et Arcadii memoranda inventa magistri / pandere [...]. Altius omnem /expediam prima repetens ab origine famam (Yet if someone's whole offspring has suddenly deserted, and he has no option from which to revive a new line, then it is time to reveal the memorable inventions of the Arcadian teacher [...]. I shall tell the entire story in depth, tracing it from its ancient origin).

Virgil's aetiological narration tells the story of the beekeeper Aristaeus, who, after having lost his bees as a result of plague, asks his mother Cyrene for help. Cyrene sends Aristaeus to the elderly Proteus, who informs him about the causes of the plague and, as a remedy, tells him he could regain his bees via the miracle of bugonia, bees ascending from a cow's carcass. This narrative pattern became extremely popular in neo-Latin literature and was taken as a starting point for countless neo-Latin aetiological myths. ${ }^{59}$ Despite the verbal allusions in the introductory verses, Giannettasio's narration is completely different. WhileVirgil's Aristaeus is a mythological figure, the protagonist of Giannettasio's epyllion is Hiero II (c.308 вСE-215 ВСE) of Syracuse. Hiero's engineers constructed a state barge, but because of its enormous dimensions it was impossible to launch the ship in the traditional way. Therefore, Hiero asks Archimedes for help and the mathematician constructs a cable- and rack-wheel-winch, which allows him to slide the ship into water. Giannettasio not only substitutes a mythical with a historical figure in his narration. While the Virgilian Aristaeus, as the reader learns, is responsible for the loss of his bees (by attempting to rape her, he had caused Eurydice's death because she was bitten by a snake when trying to escape), no guilt attaches to the protagonist of Giannettasio's story. And though Virgil's Proteus tends to retain the essential pieces of information, transforming himself into various figures and forcing Aristaeus to

59 Georg Roellenbleck, "Erzählen und Beschreiben im neulateinischen Lehrgedicht," in Acta conventus Neo-Latini Guelpherbytani (Wolfenbüttel 12.-16. August 1985), ed. Stella P. Revard, Fidel Rädle, and Mario A. di Cesare (Binghamton, NY: Center for Medieval and Early Renaissance Studies, 1988), 420-21; Heinz Hofmann, "Adveniat tandem Tiphys qui detegat orbes! Columbus in Neo-Latin Poetry, 16th-18th Centuries," in The Classical Tradition and the Americas, ed. Wolfgang Haase and Reinhold Meyer (Berlin: De Gruyter, 1994), 1:632-42 (Columbus-myth at the end of the book 8 of the Nautica); Hofmann, "Aristaeus," 367-69; Schindler, "Nicolò Partenio Giannettasio," 158n35. 
dupe him, Archimedes is cooperative from the beginning. Of course, he rejects any reward except for aeternum [...] laus et decus ortum ex illo (eternal glory) (84). The mathematician Archimedes is thus presented as an alter ego of the mathematician Giannettasio, as a Jesuit avant la lettre - serving the powerful by the means of intellectual superiority, always acting ad maiorem Dei gloriam, for the greater glory of God.

Giannettasio's Greco-Roman antiquity, as can be shown, is an antiquity viewed through Jesuit eyes. His indebtedness to local Neapolitan traditions and his numerous references to Virgil are, in the end, vehicles to communicate distinctive Jesuit values and doctrine-vehicles that, indebted to local patriotism as they might be, point to the humanistic tradition in all of Europe. 